\title{
Diversitas dan Asosiasi Tumbuhan Liar pada Lahan Padi (Oryza sativa) dan Jagung (Zea mays) di Unit Pelaksana Teknis Pengembangan Benih Palawija Singosari Kabupaten Malang \\ Diversity and Association of Wild Plants in Rice (Oryza sativa) and Corn (Zea mays) Field at Technical Implementation Unit of Palawija Seeds Development of Singosari, Malang Regency
}

\author{
Ifadotul Lailatussholiha $^{1 *}$, Ari Hayati ${ }^{2 * *}$, Hasan Zayadi ${ }^{3)}$ \\ ${ }^{123}$ Jurusan Biologi FMIPA UNISMA, Indonesia
}

\begin{abstract}
ABSTRAK
Penelitian bertujuan untuk mengetahui diversitas dan asosiasi antar spesies tumbuhan liar pada lahan tanaman padi (Oryza sativa) dan jagung (Zea mays) di UPT Pengembangan Benih Palawija Singosari Kabupaten Malang. Penelitian ini mengunakan metode Eksploratif, dengan mengamati langsung setiap tumbuhan liar yang terdapat pada lahan tanaman padi dan jagung. Pengambilan sampel tumbuhan liar dilakukan cara purposive sampling yaitu mengamati tumbuhan liar yang terdapat di sekitar pertanaman padi dan jagung pada plot-plot yang sudah ditentukan. Analisis data yang digunakan yaitu Indeks Keanekaragaman shannon-Wienner dan Indeks Kemerataan Pielou. Sedangkan untuk mengetahui asosiasi antar spesies tumbuhan liar yaitu dengan menghitung uji Chi-square berdasarkan hasil tabel kontingensi $2 \times 2$ yang nilainya didapatkan dari ada atau tidak adanya spesies dalam suatu plot. Selanjutnya untuk mengetahui positif atau negatifnya interaksi yang terjadi dilakukan perhitungan koifisien korelasi yang juga didasarkan pada tabek kontingensi $2 x 2$. Hasil yang didapatkan untuk Indeks Keanekaragaman yaitu nilai paling tinggi berada pada lahan II dari lahan tanaman jagung yaitu 2,729. Sedangkan nilai paling tinggi dari Indeks Kemeratan Pielou berada pada lahan II dari lahan tanaman jagung yaitu 0,371 .
\end{abstract}

Kata kunci: Diveritas, asosiasi, tumbuhan liar.

\begin{abstract}
The research aims to find out the diversity and association between wild plant species on rice fields (Oryza $\underline{\text { sativa) }}$ and corn (Zea mays) at technical unit of Singosari Seed Crop Development, Malang Regency. In this study using the survey method, by observing directly any wild plants found in the fields of rice and corn. The exploration of wild plants was carried out by exploratory methods, namely observing wild plants found around rice and maize plantations in predetermined plots. Analysis of the data used is the Shannon-Wienner Diversity Index and Pielou Evenness Index. Whereas to find out the association between wild plant species that is by calculating the Chi-square test based on the results of the $2 \times 2$ contingency table whose value is obtained from the presence or absence of speces in a plot. Furthermore, to find out the positive or negative interactions that occur, the correlation coefficient calculation is also based on the $2 x 2$ contingency table. The results obtained for the highest Diversity Index value of 2.729 was on land II from the corn field. Whereas the high palin value of Pielou's Tightness Index of 0.371 is on land II from the corn field.
\end{abstract}

Keywords: Diversity, association, wild plants

\footnotetext{
*) Ifadotul Lailatussholiha, Jurusan Biologi FMIPA UNISMA, Jl MT Haryono No. 193, Malang. 65144 +6282229134300 and email: ifadoang96@gmail.com

**) Dra. Ari Hayati., MP, Jurusan Biologi FMIPA UNISMA, Jl MT Haryono No. 193, Malang. 65144. +6281803844667 and email:
} aridanial29@yahoo.com

Diterima Tanggal 9 Agustus 2017 - Publikasi Tanggal 25 Agustus 2019 


\section{Pendahuluan}

Keanekaragaman spesies merupakan salah satu tema utama dalam ekologi[1]. Tumbuhan liar merupakan tumbuhan yag tumbuh secara alami (liar) bersamaan dengan tumbuhan yang sengaja ditanam. Tumbuhan tersebut seringkali dianggap sebagai pengganggu atau disebut gulma bagi para petani [2]. Akhir-akhir ini, banyak penelitian yang telah menunjukkan bahwa tumbuhan liar memiliki berbagai manfaat dalam proses pengendalian hayati, sehingga dapat dimanipulasi untuk keanekaragaman dan kelimpahan musuh alami. Tumbuhan liar yang lebih disebut sebagai gulma ternyata memiliki potensi sebagai penarik serangga-serangga dan berperan sebagai musuh alami serta dapat berfungsi sebagai proses pengendalian hama pada tanaman budidaya secara alami[3].

Tumbuhan liar merupakan mikrohabitat bagi kelangsungan hidup suatu organisme tertentu. Dalam ekosistem pertanian, mikrohabitat buatan yang baik adalah jika dibuat pada tepian atau di dalam lahan pertanian. Kemudian gulma terpilih yang ditata dalam satu lajur di lahan pertanian, tidak menunjukkan pengaruh penggulmaan yang berarti bagi tanaman budidayanya, bahkan stabilitas ekologi pertanian itu meningkat. Keanekaragaman jenis gulma dapat mempengaruhi Arthropoda di ekosistem sawah [4].

Asosiasi jenis adalah ukuran kemapuan bergabung atau keeratan antara spesies satu dengan yang lainnya. Pada dasarnya setiap makhluk hidup di bumi tak dapat hidup sendiri dan hanya hidup bersama individu-individu dan kalangannya sendiri. Hal yang idtemukan di alam adalah campuran dari berbagai spesies. meskipun ada spesies yang tidak terpengaruh dengan hadirnya spesies lain. Namun pada umumnya ada interaksi antara dua spesies atau lebih, sehingga keadaan suatu populasi spesies akan berbeda tanpa kehadiran spesies lain yang berinteraksi dengannya. Adannya interaksi ini nantinya akan menimbulkan asosiasi yang polanya sangat ditentukan oleh apakah dua spesies (sama ataupun beda) memilih untuk berada pada habitat yang sama mempunyai daya penolakan, daya tarik, atau bahkan tidak berinteraksi sama sekali [5].

Namun akhir-akhir ini sistem pertanian monokultur banyak dikembangkan dan digunakan di kalangan petani, terutama jenis tanaman pangan. Sistem pertanian tanpa disadari yang seperti ini dapat mengganggu keseimbangan agroekosistem lahan, serta dapat mengurangi vegetasi secara terus menerus dan akan mengurangi habitat lokal. Hal ini dikarenakan dalam sistem pertanian ini banyak menggunakan bahan-bahan kimia seperti pupuk kimia dan insektisida kimia secara terus menerus [6]. Selain itu, dalam sistem pertainian monkultur juga mengaplikasikan herbisida. Berdasarkan hasil survei, penggunaan herbisida mengatasi gulma yang tumbuh, dan dianggap mengganggu tanaman sehingga hasil panen dapat mengalami penurunan. Penggunaan herbisida juga dilakukan untuk pengendalian gulma yang tumbuh berdasarkan musim dan jenis tanaman yang dibudidayakan [7]

UPT Pengembangan Benih Palawija Singosari merupakan salah satu pusat pengembangan penelitian bidang pertanian yang fokus pada tanaman palawija. Salah satu tanaman palawija tersebut adalah padi (Oryza sativa) dan jagung (Zea mays). Menurut hasil wawancara, dalam pengelolaannya tanaman padi dan jagung tersebut masih menggunakan herbisida untuk membasmi berbagai tumbuhan liar yang dianggap sebagai gulma. Sehingga dapat diduga bahwa keanekaragaman komunitas padi dan jagung menurun. Untuk mengetahui kevalidan dari pendugaan tersebut, perlu dilakukannya penelitian mengenai diversitas tumbuhan yang terdapat di lahan tanaman padi dan jagung yang ada di UPT Pengembangan Benih Palawija Singosari.

\section{Material dan Metode}

\section{Bahan dan Alat}

Bahan yang digunakan dalam penelitian ini adalah semua tumbuhan liar yang terdapat pada lahan padi dan jagung di pertanaman UPT Pengembangan Benih Palawija Singosari Kabupaten Malang. Alat digunakan adalah: alat tulis, dan papan dada, serta buku Flora [8]. 


\section{Metode}

Penelitian ini berlangsung pada bulan Juni-Juli 2018 menggunakan metode eksploratif, yaitu mengamati langsung setiap tumbuhan liar yang terdapat pada lahan tanaman padi dan jagung. Pengambilan sampel tumbuhan liar dilakukan cara purposive sampling yaitu mengamati tumbuhan liar yang terdapat di sekitar pertanaman padi dan jagung pada plot-plot yang sudah ditentukan (Gambar 1.).

Pengamatan dilakukan di lahan tanaman padi dan jagung dengan luasan $\pm 3600 \mathrm{~m}^{2}$ yang telah memasuki fase generatif. Luasan lahan tersebut terbagi menjadi 6 petak, yaitu 3 petak merupakan lahan tanaman padi, dan 3 petak lain lahan tanaman jagung. Penentuan lahan penelitian yaitu lahan tanaman padi dan jagung ditentukan dengan secara sistematis dan petak sampel minimal sebanyak $10 \%$ dari luas lahan, sehingga jika dikalkulasi jumlah petak sampel adalah $80 \mathrm{~m}^{2}$. Dari 6 petak diatas, masing-masing petak akan dieltakkan 5 plot dengan ukuran $4 \mathrm{~m} \mathrm{x} 4 \mathrm{~m}$ setiap plotnya. Penempatan 5 plot setiap petaknya dapat dilihat pada Gambar 1 .

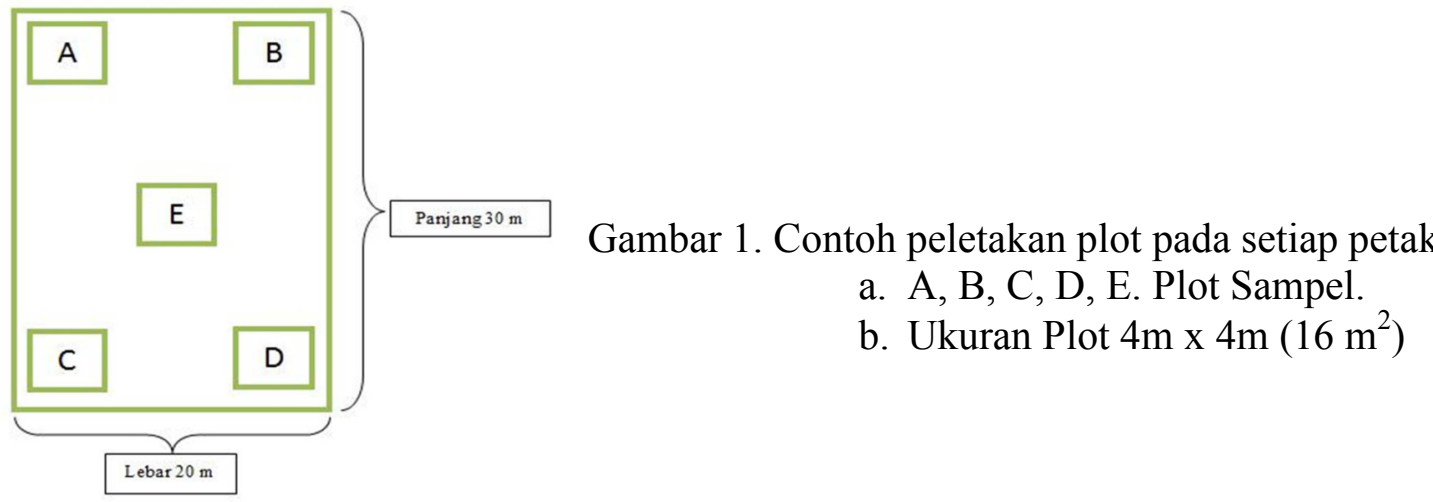

\section{Cara Kerja}

Langkah pertama dalam penelitian ini yaitu penentuan sampling tumbuhan liar. Pengamatan tumbuhan liar pada lahan tanaman budidaya padi dan jagung dilakukan di 5 plot setiap petak. Setiap plot dieksplorasi jenis-jenis tumbuhan liar yang ditemukan. Pengamatan dilakukan sebanyak 3 kali ulangan (petak) pada setiap lahan tanaman budidaya, yaitu 3 petak pada lahan tanaman padi (Oryza sativa), dan 3 petak pada lahan tanaman jagung (Zea mays). Sehingga didapatka 15 plot setiap lahan tanaman antara padi dan jagung.

Tabel 1. Tabel kontingensi 2x2

\begin{tabular}{|c|c|c|c|c|}
\hline \multicolumn{5}{|c|}{ Spesies A } \\
\hline \multirow{3}{*}{ Spesies B } & & Ada & $\begin{array}{c}\text { Tidak } \\
\text { Ada }\end{array}$ & Jumlah \\
\hline & Ada & $\mathrm{a}$ & $\mathrm{b}$ & $a+b$ \\
\hline & $\begin{array}{c}\text { Tidak } \\
\text { Ada }\end{array}$ & $\mathrm{C}$ & $\mathrm{d}$ & $\mathrm{c}+\mathrm{d}$ \\
\hline Jumlah & & $a+c$ & $\mathrm{~b}+\mathrm{d}$ & $\mathrm{N}$ \\
\hline
\end{tabular}

Tumbuhan liar yang ditemukan diambil sebanyak satu individu, dan dimasukkan kedalam plastik, untuk dilakukan identfikasi. Identifikasi dilakukan di Laboratorium Ekologi Universitas Islam Malang. Setelah dilakukan identifikasi, maka dimasukkan dalam tabel perhitungan jumlah tumbuhan 
liar tiap lahan. Identifikasi tumbuhan liar dilakukan sampai tingkat spesies menggunakan buku acuan Flora [8].

Analisis data yang diguanakan adalah Indeks keanekaragaman Shannon-Wienner, Indeks Kemerataan Pielou, dan asosiasi tumbuhan liar berdasarkan perhitungan Chi-square yang kemudian dilanjutkan dengan perhitungan koifisien korelaasi berdasarkan tabel kontingensi $2 \times 2$ (Tabel 1) menggunakan aplikasi Microsoft Excel 2010.

\section{Hasil dan Diskusi}

Berdasarkan hasil penelitian, tumbuhan liar yang didapatkan pada lahan padi jagung ditemukan 3388 jumlah individu yang berasal dari 11 spesies dari 9 familia yang termasuk dalam 8 ordo. Jumlah tersebut didominasi oleh spesies dari familia Rubiaceae yaitu Richardia brasiliensis dan spesies dari familia Cyperaceae yaitu Cyperus rotundus. Sedangkan yang paling sedikit ditemukan adalah spesies dari familia Ongraceae Ludwigya octovalvis. Sedangkan pada lahan tanaman jagung jumlah individu tumbuhan liar yang ditemukan yaitu 4434 yang berasal dari 21 spesies yang termasuk dalam 14 familia dan 13 ordo . Jumlah tersebut didominasi oleh ordo Asterales terutama suku asteraceae pada spesies Ageratum conyzoydes yaitu 803 jumlah individu. Sedangkan spesies Ludwigya octovalvis ordo myrtales dari familia yaitu onagraceae adalah jumlah yang paling sedikit ditemukan.

Indeks Keanekaragaman Tumbuhan Liar Pada Lahan Padi Dan Jagung: Indeks keanekaragaman Shannon-Wiener dihitung pada setiap petak lahan yaitu lahan I,II, dan III pada lahan tanaman padi, dan lahan I,II, dan III pada petak lahan tanaman jagung. Indeks keanekaragaman tumbuhan liar pada lahan tanaman padi dapat dilihat pada Gambar 2.

Berdasarkan aturan Shannon-Wiener, Indeks keanekaragaman (IK) dikatakan sedang apabila H' menunjukkan nilai antara 1-3, sehingga indeks keanekargaman tumbuhan liar yang terdapat pada lahan padi dan jagung termasuk dalam katagori sedang. IK yang terdapat pada lahan jagung meiliki hasil perhitungan yang lebih tinggi, dibandingkan dengan hasil perhitungan nilai yang terdapat pada lahan tanaman padi. IK yang paling tinggi berada pada lahan ke II dari tanaman jagung, sedangkan indeks paling rendah berada pada lahan ke III dari tanaman padi.

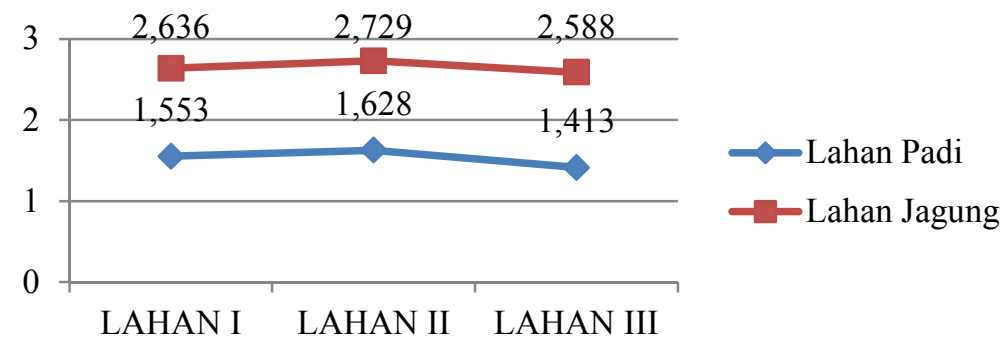

Gambar 2. Indeks Keanekaragaman Tumbuhan Liar pada Lahan Tanaman Padi dan Jagung di Masing-masing Lahan

Indeks Kemerataan Tumbuhan Liar Pada Lahan Padi Dan Jagung: Indeks kemerataan Pielou dihitung berdasarkan spesies tiap petak lahan, yaitu 3 petak pada lahan tanaman padi dan jagung. Untuk menghitung yaitu membagi hasil indeks keanekaragaman dengan ln dari jumlah spesies dalam petak. Hasil perhitungan indeks kemerataan spesies pada setiap lahan terdapat pada Gambar 3.

Indeks kemerataan spesies Pielou pada setiap lahan padi dan jagung, memiliki hasil nilai yang sangat rendah. Setiap petak lahannya terletak pada rentang antara $0,00-0,50$ yang artinya menunjukkan kondisi tumbuhan tertekan. Namun nilai indeks Kemerataan tumbuhan liar pada lahan padi lebih rendah daripada indeks Kemerataan lahan tanaman jagung. Rendahnya nilai indeks kemerataan tersebut, mungkin dikarenakan tidak stabilnya jumlah individu dari spesies. Ada spesies yang jumlahnya sangat tinggi seperti Richardia brasiliensis dan Cyperus rotundus pada lahan 
tanaman padi, Synedrella nodiflora dan Ageratum conyzoides pada lahan tanaman Jagung. Ada juga yang jumlah spesies dengan julah sangat rendah, seperti Ludwigya octovalvis baik pada lahan tanaman padi maupun tanaman jagung.

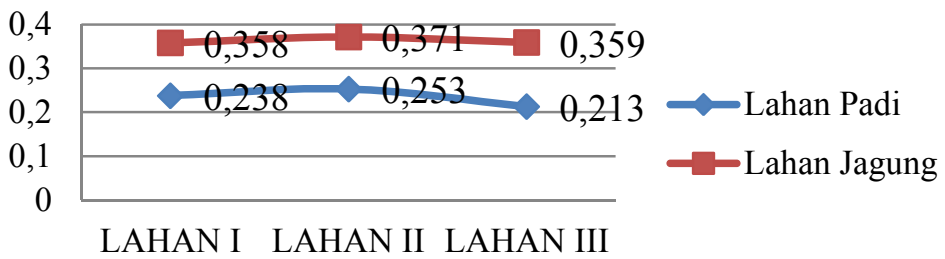

Gambar 3. Hasil Indeks Kemerataan Tumbuhan Liar Pada Lahan Tanaman Padi dan Jagung.

\begin{abstract}
Asosiasi Antar Spesies Tumbuhan Liar Pada Lahan Padi Dan jagung: Asosiasi antara dua spesies didasarkan pada pengukuran secara kuantitatif ada tidaknya spesies pada petak yang diamati yang diukur. Berdasarkan tabel kontingensi $2 \times 2$, dan rumus yang telah ditentukan diatas didapatkan hasil perhitungan asosiasi tumbuhan liar yang terdapat pada lahan padi. Berdasarkan tabel kontingensi $2 \times 2$, asosiasi antar spesies tumbuhan liar pada lahan padi memiliki 55 pasang antara spesies satu dengan yang lain. Ke 55 pasangan ini, setiap pasangannya dilakukan uji Chi-square,untuk mengetahui adanya interaksi antarn2 spesies . Nilai yang menunjukkan lebih dari 3,841 berarti menunjukkan bahwa ada interaksi antar dua spesies yang dipasangakan. Hasil hitung tertinggi terdapat pada pasangan Centella asiatica dan Physalis angulata yang menunjukkan nilai 6,56. Sedangkan nilai yang menunjukkan kurang dari 3,841 menunjukkan tidak adanya interaksi antar spesies tumbuhan liar yang dipasangkan. Tumbuhan yang memiliki interaksi terdiri dari 11 pasang, sedangkan 44 lainnya tergolong tidak memiliki interaksi.
\end{abstract}

Tabel 2. Hasil Perhitungan Koifisien Korelasi Interaksi Tumbuhan Liar pada Lahan Padi menggunakan tabel Kontingensi $2 \times 2$.

\begin{tabular}{crrrrrrrrrrr}
\hline $\begin{array}{c}\text { Kode } \\
\text { Spesies }\end{array}$ & $\mathbf{1}$ & $\mathbf{2}$ & $\mathbf{3}$ & $\mathbf{4}$ & $\mathbf{5}$ & $\mathbf{6}$ & $\mathbf{7}$ & $\mathbf{8}$ & $\mathbf{9}$ & $\mathbf{1 0}$ & $\mathbf{1 1}$ \\
\hline $\mathbf{1}$ & - & 0 & 0.03 & -0.01 & -0.03 & 0 & -0.01 & 0.03 & -0.02 & 0.02 & -0.01 \\
$\mathbf{2}$ & - & - & 0 & 0 & 0 & 0 & 0 & 0 & 0 & 0 & 0 \\
$\mathbf{3}$ & - & - & - & -0.014 & 0.008 & 0 & 0.004 & 0.004 & -0.004 & 0.007 & 0.004 \\
$\mathbf{4}$ & - & - & - & - & -0.009 & 0 & -0.014 & -0.014 & 0.02 & 0.018 & -0.011 \\
$\mathbf{5}$ & - & - & - & - & - & 0 & 0.02 & 0.008 & -0.007 & 0.014 & -0.008 \\
$\mathbf{6}$ & - & - & - & - & - & - & 0 & 0 & 0 & 0 & 0 \\
$\mathbf{7}$ & - & - & - & - & - & - & - & 0.009 & -0.014 & 0.018 & -0.015 \\
$\mathbf{8}$ & - & - & - & - & - & - & - & - & -0.014 & 0.026 & -0.015 \\
$\mathbf{9}$ & - & - & - & - & - & - & - & - & - & -0.012 & 0.022 \\
$\mathbf{1 0}$ & - & - & - & - & - & - & - & - & - & - & - \\
$\mathbf{1 1}$ & - & - & - & - & - & - & - & - & - & - & - \\
\hline
\end{tabular}

Ket: tanda (-) menunjukkan bahwa interaksi sudah tercatat atau sudah ada pada kolom sebelumnya.

(1)Centella asiatica; (2)Richardia brasiliensis; (3)Eclipta prostate; (4)Cyperus rotundus; (5)Physalis angulata L.; (6)Commelina nudiflora; (7)Oxalis corniculata; (8)Acmella paniculata; (9)monochoria vignalis; (10)Ludwigya octovalvis; (11)Ageratum conyzoydes. 
e-Jurnal Ilmiah BIOSAINTROPIS (BIOSCIENCE-TROPIC)

Volume 5 / No.:1 / Halaman 18 - 24 / Agustus Tahun 2019

ISSN : 2460-9455 (e) - 2338-2805(p)

Tabel 3. Hasil perhitungan koifisien korelasi Interaksi tumbuhan liar pada lahan jagung menggunakan

Tabel kontingensi $2 \times 2$

\begin{tabular}{|c|c|c|c|c|c|c|c|c|c|c|c|c|c|c|c|c|c|c|c|c|}
\hline $\begin{array}{l}\text { Kode } \\
\text { Spesies }\end{array}$ & 1 & 2 & 3 & 4 & 5 & 6 & 7 & 89 & 10 & 11 & 12 & 13 & 14 & 15 & 16 & 17 & 18 & 19 & 20 & 21 \\
\hline 1 &. & 0 & 0 & 0 & 0 & 0 & 0 & 00 & 0 & 0 & 0 & 0 & 0 & 0 & 0 & 0 & 0 & 0 & 0 & 0 \\
\hline 2 &. & . & 0 & 0 & 0 & 0 & 0 & 00 & 0 & 0 & 0 & 0 & 0 & 0 & 0 & 0 & 0 & 0 & 0 & 0 \\
\hline 3 & . & . & . & $.0,01$ & 0,01 & 0 & 0 & \begin{tabular}{l|l}
0 & 0 \\
\end{tabular} & 0,143 & 0,143 & 0,143 & 0,143 & 0 & 0,10 & 0 & $.0,014$ & 0 & 0,011 & 0,036 & 0 \\
\hline 4 &. & . &. & . & 0 & 0.071 & 0 & 00 & $.0,01$ & $.0,01$ & $.0,01$ & $.0,01$ & 0 & $.0,01$ & 0 & $\cdot 0,014$ & 0 & 0,011 & $.0,013$ & 0 \\
\hline 5 &. & . &. & . & . & 0 & 0 & 00 & 0 & 0 & 0 & 0 & 0 & 0 & 0 & 0 & 0 & 0 & 0 & 0 \\
\hline 6 &. & . & . & . & . & . & 0 & 00 & $.0,011$ & $\cdot 0,011$ & $.0,011$ & $\cdot 0,011$ & 0 & $.0,015$ & 0 & $\cdot 0,012$ & $\cdot 0,014$ & $.0,012$ & $.0,014$ & 0 \\
\hline 7 &. & . &. & . & . & . &. & 00 & 0 & 0 & 0 & 0 & 0 & 0 & 0 & 0 & 0 & 0 & 0 & 0 \\
\hline 8 &. & . &. & . & . & . &. & .0 & 0 & 0 & 0 & 0 & 0 & 0 & 0 & 0 & 0 & 0 & 0 & 0 \\
\hline 9 &. & . & . & . & . & . &. &. & 0 & 0 & 0 & 0 & 0 & 0 & 0 & 0 & 0 & 0 & 0 & 0 \\
\hline 10 & . & . & . & . & . & . &. &. & . & 0.143 & 0.143 & 0.143 & 0 & $.0,010$ & 0 & $.0,014$ & 0 & 0,11 & 0,036 & 0 \\
\hline II &. & . &. & . & . & . &. & .5 & . & . & 0,143 & 0,143 & 0 & 0,10 & 0 & 0,014 & 0 & 0,011 & 0,033 & 0 \\
\hline 12 &. & . &. & . & . & . &. & .5 & . & . & - & 0,143 & 0 & $.0,010$ & 0 & $.0,014$ & 0 & 0,011 & 0,036 & 0 \\
\hline 13 &. & . & . & $\dot{.}$ & . & . &. &. & . & . & . &. & 0 & $.0,010$ & 0 & $.0,014$ & 0 & 0,011 & 0,036 & 0 \\
\hline 14 &. & . & . & . & . & . &. & .5. & . & . & . &. &. & 0 & 0 & 0 & 0 & 0 & 0 & 0 \\
\hline 15 &. & . &. & . & . & . &. & .5. & . & . & . & . &. & . & 0 & 0,033 & 0 & $.0,048$ & 0,021 & 0 \\
\hline 16 & . & . & . & . & . & . &. & .5. & . & . & . & . & . & . &. & 0 & 0 & 0 & 0 & 0,015 \\
\hline 17 &. & . &. & . & . & . &. & .5. & . & . & . &. &. &. &. & . & 0 & 0,008 & 0,009 & 0 \\
\hline 18 &. & . & . & . & . & . &. &. & . & . & . &. & . & . &. & . &. & . & 0,012 & 0 \\
\hline 19 &. & . &. & . & . & . &. & .5 & & . & . &. & . &. &. & . & . &. & . & 0 \\
\hline 20 &. & $\dot{.}$ &. & . & . & . &. & .5. & . & . & . &. & $\cdot$ &. &. & . &. & . & . & . \\
\hline 21 & . & . & . & & & . &. & & & & & &. & &. & & 4 & & & \\
\hline
\end{tabular}

Ket: tanda (-) menunjukkan bahwa interaksi sudah tercatat atau sudah ada pada kolom sebelumnya. (1)Ageratum conyzoides; (2)Mimosa pudica; (3)Cyperus rotundus; (4)Centella asiatica; (5)Phylanthus urinaria; (6)Euphorbia hirta; (7)Amaranthus spinosus; (8)Crassocephalum crepidiodies; (9)Emilia sonchifolia; (10)Rorippa indica; (11)Laportea stimulans; (12)Echiochloa colona; (13)Ricardia brasiliensis; (14)Drymaria cordata; (15)Commelina nudiflora; (16)Oxalis corniculata; (17)Eclipta prostata (18)Synedrella nodiflora; (19)Ludwigya octovalvis; (20)Acmella paniculata; (21)Elephantopus scaber;

Pada lahan jagung, asosiasi antar spesies lainnya terdiri dari 210 pasang yang selanjutnya dilakukan uji Chi-square untuk mengetahui adanya interaksi antara tumbuhan liar satu dengan yang laninya berdasarkan tabel kontingensi $2 \times 2$. Hasil uji Chi-square menunjukkan bahwa tumbuhan yang memiliki interaksi antar kedua spesies tumbuhan liar terdiri dari 17 pasang, sedangkan 193 lainnya tidak memiliki interaksi, karena menujukkan nilai kurang dari 3,481.

Setelah dilakukan uji Chi-square, tahap selanjutnya adalah penentuan koifisien korelasi interaksi antar spesies untuk menetukan interaksi benilai positif atau negatif. Nilai korelasi yang positif menunjukkan adanya hubungan yang erat antara spesies yang dipasangkan, dan keeratan hubungan terletak pada tingginya titik koifisien korelasi ${ }^{[7]}$. Berdasarkan hasil perhitungan pada lahan padi (tabel 2.), nilai koifisien interaksi antar tumbuhan liar pada lahan padi memiliki nilai yang relatif rndah dimana nilai tertinggi yaitu 0,03 tedapat pada pasangan Centella asiatica dan Eclipta prostata serta pasangan Centella asiatica dan Acmella paniculata. Pada lahan Jagung (tabel 3.), nilai koifisien korelasi teringgi 0,143 terdapat pada beberapa pasangan. Pada hasil hitung nilai Koifisien interaksi tumbuhan liar, nilai tertinggi baik pada lahan padi dan jangung merupakan pasangan yang tidak memilki interaksi berdasarkan hasil uji Chi-square. 


\section{Kesimpulan}

Indeks keanekaragaman ( $\left.\mathrm{H}^{\prime}\right)$ Shannon-Wiener dari tumbuhan liar yang terdapat pada lahan padi dan jagung tergolong dalam kategori sedang. Indeks kemerataan pada padi dan jagung termasuk dalam kategori terancam karena tidak stabilnya jumlah individu yang terdapat pada setiap spesies. Asosiasi antar spesies tumbuhan liar pada lahan padi hasil hitung tertinggi terdapat pada pasangan Centella asiatica dan Physalis angulata yang menunjukkan nilai 6,56. Pada lahan jagung, asosiasi antar spesies terdapat pada pasangan spesies Commelina nudiflora dan Ludwigya octovalvis. Berdasarkan hasil perhitungan pada lahan padi, nilai koifisien interaksi antar tumbuhan liar pada lahan padi memiliki nilai yang relatif rendah dimana nilai tertinggi yaitu 0,03 tedapat pada pasangan Centella asiatica dan Eclipta prostata serta pasangan Centella asiatica dan Acmella paniculata. Pada lahan Jagung, nilai koifisien korelasi teringgi yaitu 0,143 terdapat pada beberapa pasangan antar spesies tumbuhan liar.

Saran yang dapat diberikan adalah perlu adanya penelitian lebih lanjut mengenai interaksi antar spesies tumbuhan liar yang terdapat pada lahan budidaya lain, sehingga dapat diketahui potensi atau peranan pentingnya gulma atau tumbuhan liar dalam suatu komunitas. Dengan diketahuinya potensi tersebut maka penggunan herbisida lebih minim yaitu lebih fokus pada tumbuhan yang lebih merugikan pada suatu lahan terutama lahan tanaman budidaya.

\section{Daftar Pustaka}

[1]Qomariyah,N., Hayati, A. dan Zayadi, H. 2018. Diversitas Serangga Predator Yang Dating Pada Lahan Tanaman Cabai Rawit (Capsicum frutescens L.) Berdasarkan Variasi Temporal di Desa Bumi Anyar Kecamatan Tanjungbumi Kabupaten Bangkalan. Jurnal: Biosaintropis. Vol. 4 No. 1. Hal. 22-30.

[2]Nugroho, A. S., Anis,T. dan Ulfah, M. 2015. Analisis keanekaragaman jenis tumbuhan berbuah di hutan lindung Surokonto, Kendal, Jawa Tengah dan potensinya sebagai kawasan konservasi burung. Pros Sem Nas Masy Biodiv Indon. Vol. 01, No.3. ISSN: 2407-8050. Hal: 472-476.

[3]Addina, L, Yanuwiadi, B., Gama, Z.P. dan Leksono, A.S. 2013. Efek Perpaduan Beberapa Tumbuhan Liar Di Sekitar Area Pertanaman Padi Dalam Menarik Arthropoda Musuh Alami Dan Hama. El-Hayah Vol. 3, No.2. Hal 71-78.

[4]Allifah, A.N., Yanuwiadi , B., Gama, Z.P., Leksono, A.S. 2013. Refugia Sebagai Mikrohabitat Untuk Meningkatkan Peran Musuh Alami Di Lahan Pertanian. Prosiding FMIPA Universitas Pattimura. ISBN: 978-602-97522-0-5.

[5]Paillin, J.B. 2009. Asosiasi Inter Spesies Lamun di Perairan Ketapang Kabupaten Seram Bagian Barat. Jurnal Triton. Vol. 5.No. 2. Hal: 19-25.

[6]Erdiansyah, Iqbal, dan Putri, S.U. 2017. Optimalisasi Fungsi Bunga Refugia Sebagai Pengendali Hama Tanaman Padi (Oryza Sativa L.). Seminar Nasional Hasil Penelitian. ISBN: 978-60214917-5-1.

[7]Fadhly dan Tabri. 2009. Pengendalian Gulma pada Pertanaman Jagung. Balai Penelitian Tanaman Serealia. Maros.

[8]Steenis, C.G.G.J. Van . 2013. Flora. Balai Pustaka. Jakarta. 